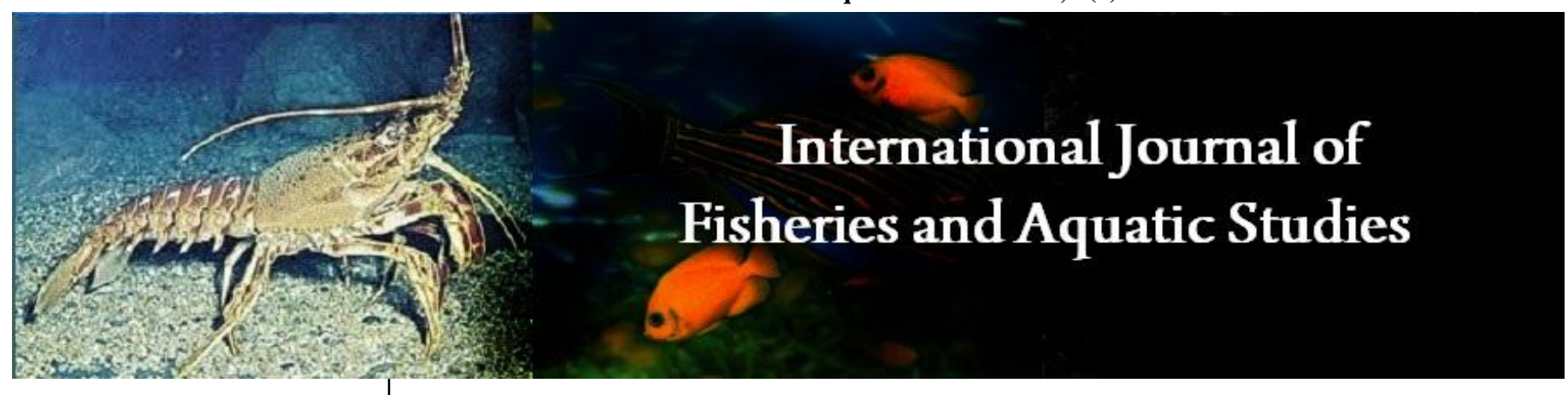

E-ISSN: 2347-5129

P-ISSN: 2394-0506

(ICV-Poland) Impact Value: 5.62

(GIF) Impact Factor: 0.549

IJFAS 2020; 8(5): 375-379

(C) 2020 IJFAS

www.fisheriesjournal.com

Received: 20-07-2020

Accepted: 22-08-2020

Shailendra Sharma

Devi Ahilya Vishwa Vidhalaya,

Indore, Madhya Pradesh, India

Hemendra Wala

Devi Ahilya Vishwa Vidhalaya, Indore, Madhya Pradesh, India

Rekha Sharma

Devi Ahilya Vishwa Vidhalaya, Indore, Madhya Pradesh, India
Corresponding Author:

Hemendra Wala

Devi Ahilya Vishwa Vidhalaya,

Indore, Madhya Pradesh, India

\section{Ichthyofaunal diversity and productivity of Dilawara reservoir of Dhar district, Madhya Pradesh}

\author{
Shailendra Sharma, Hemendra Wala and Rekha Sharma
}

DOI: https://doi.org/10.22271/fish.2020.v8.i5e.2346

\begin{abstract}
Samplings of fish were done from four sampling sites of Dilawara reservoir of Dhar Tehsil, Madhya Pradesh, for two consecutive years from January 2017 to December 2018 to assess the ichthyofaunal diversity. A total of 27 species belonging to 7 orders, 14 families and 21 genera were recorded during the present study. Order Cypriniformes was the most dominant among the 7 orders of fish recorded with 11 species followed by Order Perciformes with 8 species. Order Siluriformes was represented by 4 species. Order Clupeiformes, Order Osteoglossiformes, Order Beloniformes and Order Synbranchiformes were represented by single species each. The Simpson's diversity index varied from 0.04 during winter 2017 to0.08 during Post Monsoon 2018. The Shannon - Weiner index swing in between 2.5 during Monsoon 2017 to 3.02 during winter 2018. The fish abundance was also compared among the environmental factors of season; some species were season specific, for example Notopterus notopterus, Glossogobius gluris, Clarias batrachus and Nastacembalus armatus. Of the total species identified, seven species were found in all the seasons.
\end{abstract}

Keywords: Dilawara reservoir, ichthyofaunal diversity, environmental factors, fish abundance

\section{Introduction}

Biodiversity indicates the potential of any aquatic system and also depicts its trophic status. It is important to have an adequate knowledge of the constituent biota especially for the purpose of conservation and management of the inland water resources such as rivers, reservoirs and ponds. Fishes constitute half of the total number of vertebrates in the world 21,723 living species of fish out of 39,900 species of vertebrates are so for recorded (Jayaram, $1999{ }^{[4]}$ ) The freshwater fishes are distributed amongst approximately 20 orders, 100 families and 300 genera (Daniels et al., $2000^{[2]}$ ). Reservoirs conserve a variety of native riverine fish species as well as introduced species which leads and supports commercial fisheries. The understanding of fish faunal diversity is a major gateway for the exploitation of fresh water reservoirs for food (Battul et al., $2007^{[1]}$ ). During the last few decades, the fish biodiversity of the country has been declining rapidly due to anthropogenic environmental degradation like urbanization, damming, abstraction of waters for irrigation and power generation, and pollution, which have subjected the natural water bodies in general and rivers in particular to severe stress with

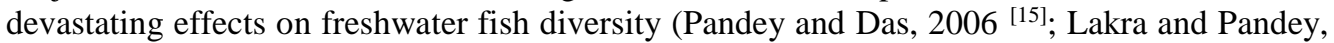
2009 [[; Tiwari, $2011^{[17]}$; Kumar et al., $2013^{[7]}$; Kumar and Pandey, $2013^{[8]}$ ). Indian reservoirs preserve a rich variety of fish species, which supports to the commercial fisheries (Thirumala et al., $\left.2011^{[16]}\right)$. Fish species are also an important indicator of ecological health. The abundance and health of fish show the health of water bodies (Hamzah, $2007^{[3]}$ ). The objectives of the present study were to document the fish diversity and productivity in Dilawara reservoir and suggest appropriate conservation and management strategies.

\section{Materials and Methods}

Study area and sites for research

Sampling Sites: The proposed investigation was carried out in the four selected sampling stations of Dilawara reservoir located in Dhar tehsil of Dhar district in Madhya Pradesh, India from January 2017 to December 2018. Most water comes from Dilawari river and rain water. Reservoir is drinking water source of Dhar district population. It is situated $18 \mathrm{~km}$ away from Dhar. The total geographical area of village is 1086.69 hectares. 


\section{Collection of fishes}

Fishes were collected with the help of local fishermen by using cast nets of various sizes. For very small fishes, modified methods for collection, such as cloths and bottles were used. All the specimens were preserved in $4 \%$ formaldehyde solution at the field.

\section{Laboratory Procedures}

After collection the number was counted and recorded. All the specimens were preserved in $10 \%$ formalin solution in separate specimen jar according to the size of specimen and identification was done using keys developed by (Koumans

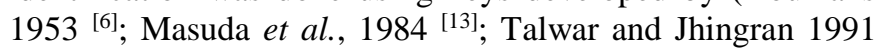
$\left.{ }^{[15]}\right)$ ). Relative abundance was calculated by using the formula

$$
\mathrm{RA}=\frac{\text { number of individuals of a species }}{\text { number of individuals of all species }} \times 100
$$

\section{Data analysis}

To quantify the diversity of the assemblage and for the statistical comparison of the diversity at four different sampling stations of the study area Simpson index of diversity and Shannon-Weiner index with the help of software PAST, version 2.15 were used.

\section{Results and Discussion}

A complete check list of the fish species recorded during the present study is presented in table 1 and figure 1 . Present study recorded presence of 27 species of fishes belonging to 7 Orders (Clupeiformes, Cypriniformes, Ophiocephaliformes, Siluriformes, Perciformes, Beloniformes, and Synbranchiformes) and 14 families (Clupeidae, Notopteridae Cyprinidae, Siluridae, Bagridae, Claridae, Heteropneustidae, Ambassiidae, Anabantidae, Nandidae, Belonidae, Ophiocephalidae, Mastacembilidae and Gobiidae) and 21 genera (Cudusia, Notopterus, Rasbora, Garra, Puntius, Osteobrama, Osteobrama, Catla, Cirrhinus, Labeo, Cyprinus, Wallago, Mystus, Heteropneustus, Clarias, Chanda, Colisa, Glossogobius, Nandus, Channa, Xenentodon and Mastacembalus during 2017-2018. Order Clupeiformes, Family- Clupeidae and genus Cudusia consists of 1 speciesCudusiachapra. Order Osteoglossiformes, Family Notopteridae and genus Notopterus also consists of only1 species - Notopterus notopterus. Order CypriniformesFamily- Cyprinidae consists of 8 genera Rasbora, Garra, Puntius, Osteobrama, Catla, Cirrhinus, Labeo and Cyprinus and 11 fish species Rasbora daniconius, Garra gotyala, Puntius sarana, Puntius ticto, Osteobramacotio, Catla catla, and Cirrhinus mrigale, Labeo rohita, Labeo calbasu, Labeo gonius. Order Siluriformes consists of four families Siluridae, Bagridae, Heteropneustidae and Clariidae, four genera viz: Wallago, Mystus, Heteropneustus and Clarias and four species viz: Wallago attu, Mystus seenghala, Heteropneustes fossillis and Clarias batrachus. Order Perciformes consist of five families viz: Ambassiidae, Anabantidae, Gobiidae, Nandidae and Ophiocephalidae five genera- Chanda,

Colisa, Glossogobius, Nandus and Channa and eight species viz: Chanda rama, Chanda ranga, Colisa faciatus, Glossogobius gluris, Nandus nandus, Channa punctatus, Channa striatus and Channa gachua Order Beloniformes, Family- Belonidae, genus- Xenentodon consist of only one species- Xenentodoncancila. Order Synbranchiformes familyMastacembalidae genus Mastacembalus consist of only one species- Mastacembalus armatus.

Order Cypriniformes was the most dominant among the 7 orders of fish recorded with 11 species followed by Order Perciformes with 8 species. Order Siluriformes is represented by4 species. Order Clupeiformes, Order Osteoglossiformes, Order Beloniformes and Order Synbranchiformes were represented by single species each. Earlier researchers like (Battul et al., $2007^{[1]}$ ) reported 18 fish species from Ekrukh reservoir of Maharashtra where Cyprinidae family is dominant with 8 species. (Khedkar and Gynanath, $2005^{[5]}$ ) recorded 37 species from Issapur dam of Maharashtra where Cyprinidae family is dominant with 20 species. The ichthyofauna of Ambadi dam (Maharashtra) was reported by (Ubarhande et al., $2011^{[18]}$ ) which belong to 8 orders, 11 families, 22 genera and 27 species where Cyprinidae family is dominant with 13 species which makes $48.16 \%$ of total fish. The ichthyofauna of Kolisagar reservoir (Telangana) was reported by (Laxmappa et al., $2014{ }^{[10]}$ ) which belongs 06 orders 12 families, 22 genera and 30 species where Cyprinidae family is dominant represented by 13 species $44 \%$ of the total fish.

The fish abundance was compared among the environmental factors of season (Monsoon was defined as the period from June to August, Post Monsoon from September to November, winter from December to February and summer from March to May). Some species were season specific, for example Notopterus notopterus, Glossogobiusgluris, Clariasbatrachus and Nastacembalusarmatus were not recorded in all seasons of both the years except monsoon season. Fish speciesCudusiachapra, Garragotyala and Cyprinuscarpio were totally absent during winter season of both the years. Species like Rasboradaniconius, Puntius sarana, Puntius ticto Osteobramacotio and Colisafaciatus were recorded in all the seasons but were completely absent during summer season of both the years Mystusseenghala and Xenentodoncancila were present in all seasons except post monsoon season. Of the total species, seven species were found all the seasons as presented in table 2 .

According to (Mondal and Kaviraj, $2009^{[11]}$ and Mondal et al., $2010^{[12]}$ number of fish species and the species density fluctuated between the seasons. (Mustapha, $2009^{[14]}$ ) reported that the warm temperature and high transparency in the dry season promoted high fish catches in Nigerian reservoirs.

\section{Statistical estimation of species diversity}

The various estimates of richness showed the of species richness in monsoon, postmonsoon and pre-monsoon. The Simpson's diversity index values of the year 2017 during Monsoon, Post Monsoon, winter and summer were 0.07, 0.05, 0.04 and 0.06 . The respective Simpson's diversity index values of the year 2018 were $0.05,0.08,0.05$ and0.06. The Simpson's diversity index varied from 0.04 during winter 2017 to0.08 during Post Monsoon 2018.

Shannon - Weiner index values of the year 2017 during Monsoon, Post Monsoon, winter and summer were 2.5, 2.88, 3.02 and 2.7. The respective Shannon - Weiner index values of the year 2018 were $2.8,2.52,2.95$ and 2.71. The ShannonWeiner index swing in between 2.5 during Monsoon 2017 to 3.02 during winter 2018 as shown in table 3 and Figure 2a-b. Mondal and Kaviraj, $2009{ }^{[11]}$ indicated that there was a trend of increase in the Shannon-Weaver index and evenness index This was due to gradual reduction in number of individuals of the dominant species resulting in a gradual reduction of index of dominance. 
Table 1: Fish Fauna recorded from Dilwara reservoir from the four selected study sites from January 2017-December 2018

\begin{tabular}{|c|c|c|c|c|}
\hline Order & Family & Genus & Fish Species & Total \\
\hline Clupeiformes & Clupeidae (18) & Cudusia & Cudusiachapra & 18 \\
\hline Osteoglossiformes & Notopteridae (41) & Notopterus & Notopterus notopterus & 41 \\
\hline \multirow{11}{*}{ Cypriniformes } & Cyprinidae(444) & Rasbora & Rasboradaniconius & 34 \\
\hline & & Garra & Garragotyala & 11 \\
\hline & & \multirow{2}{*}{ Puntius } & Puntius sarana & 41 \\
\hline & & & Puntius ticto & 30 \\
\hline & & Osteobrama & Osteobramacotio & 4 \\
\hline & & Catla & Catlacatla & 57 \\
\hline & & Cirrhinus & Cirrhinusmrigale & 56 \\
\hline & & \multirow{3}{*}{ Labeo } & Labeorohita & 75 \\
\hline & & & Labeocalbasu & 66 \\
\hline & & & Labeogonius & 57 \\
\hline & & Cyprinus & Cyprinuscarpio & 13 \\
\hline \multirow{4}{*}{ Siluriformes } & Siluridae (71) & Wallago & Wallago attu & 71 \\
\hline & Bagridae (65) & Mystus & Mystusseenghala & 65 \\
\hline & Heteropneustidae(82) & Heteropneustus & Heteropneustesfossillis & 82 \\
\hline & Clariidae (68) & Clarias & Clariasbatrachus & 68 \\
\hline Perciformes & \multirow{2}{*}{ Ambassiidae (121) } & \multirow{2}{*}{ Chanda } & Chanda rama & 65 \\
\hline & & & Chanda ranga & 56 \\
\hline & Anabantidae (27) & Colisa & Colisafaciatus & 27 \\
\hline & Gobiidae 38) & Glossogobius & Glossogobiusgluris & 38 \\
\hline & Nandidae (35) & Nandus & Nandusnandus & 35 \\
\hline & \multirow{3}{*}{ Ophiocephalidae (173) } & \multirow{3}{*}{ Channa } & Channa punctatus & 38 \\
\hline & & & Channastriatus & 83 \\
\hline & & & Channagachua & 52 \\
\hline Beloniformes & Belonidae (18) & Xenentodon & Xenentodoncancila & 18 \\
\hline Synbranchiformes & Mastacembalidae(29) & Mastacembalus & Mastacembalusarmatus & 29 \\
\hline
\end{tabular}

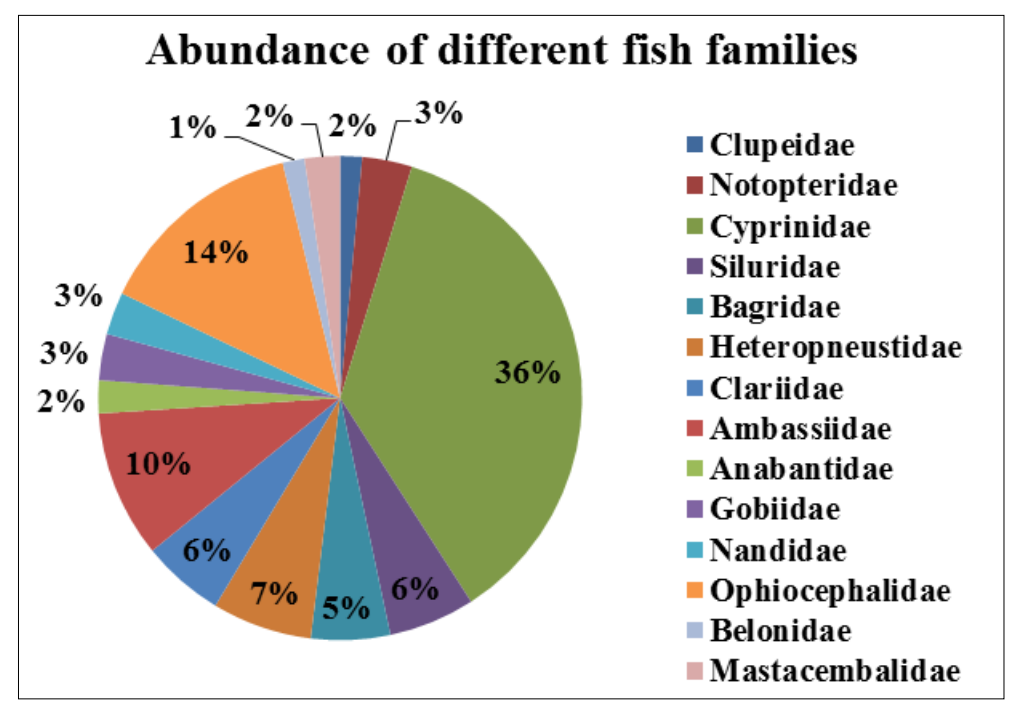

Fig 1: Abundance of different fish families at four sampling stations of Dilwara Reservoir from January 2017-December 2018

Table 2: Seasonal variations in fishes of Dilawara Reservoir during 2017 and 2018

\begin{tabular}{|c|c|c|c|c|c|c|c|c|c|}
\hline \multirow{2}{*}{ S. No. } & \multirow{2}{*}{ Name of fish } & \multicolumn{4}{|c|}{2017} & \multicolumn{4}{|c|}{2018} \\
\hline & & Monsoon & Post Monsoon & Winter & Summer & Monsoon & Post Monsoon & Winter & Summer \\
\hline 1 & Cudusiachapra & - & - & - & + & + & + & - & - \\
\hline 2 & Notopterus notopterus & - & ++ & ++ & - & - & - & ++ & + \\
\hline 3 & Rasboradaniconius & + & ++ & +++ & - & - & - & - & - \\
\hline 4 & Garragotyala & - & + & - & + & - & - & - & - \\
\hline 5 & Puntius sarana & - & + & ++ & - & + & + & +++ & - \\
\hline 6 & Puntius ticto & - & - & ++ & - & + & - & ++ & - \\
\hline 7 & Osteobramacotio & - & - & + & - & - & - & - & - \\
\hline 8 & Catlacatla & + & + & +++ & + & + & + & +++ & + \\
\hline 9 & Cirrhinusmrigale & + & + & +++ & + & + & + & +++ & + \\
\hline 10 & Labeorohita & + & + & +++ & + & + & + & +++ & ++ \\
\hline 11 & Labeocalbasu & + & ++ & +++ & + & + & - & +++ & + \\
\hline 12 & Labeogonius & + & + & +++ & + & + & - & +++ & + \\
\hline 13 & Cyprinuscarpio & - & + & - & - & - & - & - & + \\
\hline
\end{tabular}




\begin{tabular}{|c|c|c|c|c|c|c|c|c|c|}
\hline 14 & Wallago attu & + & ++ & + & ++ & + & + & ++ & ++ \\
\hline 15 & Mystusseenghala & + & - & +++ & ++ & + & - & +++ & - \\
\hline 16 & Neteropneustesnotopterus & + & ++ & ++ & + & + & ++ & + & ++ \\
\hline 17 & Clariasbatrachus & - & + & ++ & + & - & - & +++ & ++ \\
\hline 18 & Chanda rama & + & + & + & + & + & + & ++ & ++ \\
\hline 19 & Chanda ranga & + & + & + & + & + & ++ & + & + \\
\hline 20 & Colisafaciatus & - & - & + & - & + & + & + & - \\
\hline 21 & Glossogobiusgluris & - & ++ & ++ & + & - & - & - & - \\
\hline 22 & Nandusnandus & - & + & - & - & + & + & ++ & + \\
\hline 23 & Channa punctatus & - & - & + & - & + & + & + & ++ \\
\hline 24 & Channastriatus & + & ++ & ++ & ++ & - & ++ & ++ & + \\
\hline 25 & Channagachua & - & ++ & ++ & + & + & + & + & + \\
\hline 26 & Xenentodoncancila & + & - & - & + & - & - & + & - \\
\hline 27 & Nastacembalusarmatus & - & + & + & - & - & - & + & + \\
\hline
\end{tabular}

Table 3: Diversity indices of fish species in different seasons of the year 2017 and 2018

\begin{tabular}{|c|c|c|c|c|c|c|c|c|}
\hline \multicolumn{2}{|c|}{2017} & \multicolumn{4}{c|}{$\mathbf{2 0 1 8}$} \\
\hline Diversity indices & Monsoon & Post Monsoon & Winter & Summer & Monsoon & Post Monsoon & Winter & Summer \\
\hline Simpson index & 0.07 & 0.05 & 0.04 & 0.06 & 0.05 & 0.08 & 0.05 & 0.06 \\
\hline Shannon index & 2.5 & 2.88 & 3.02 & 2.7 & 2.8 & 2.52 & 2.95 & 2.71 \\
\hline
\end{tabular}

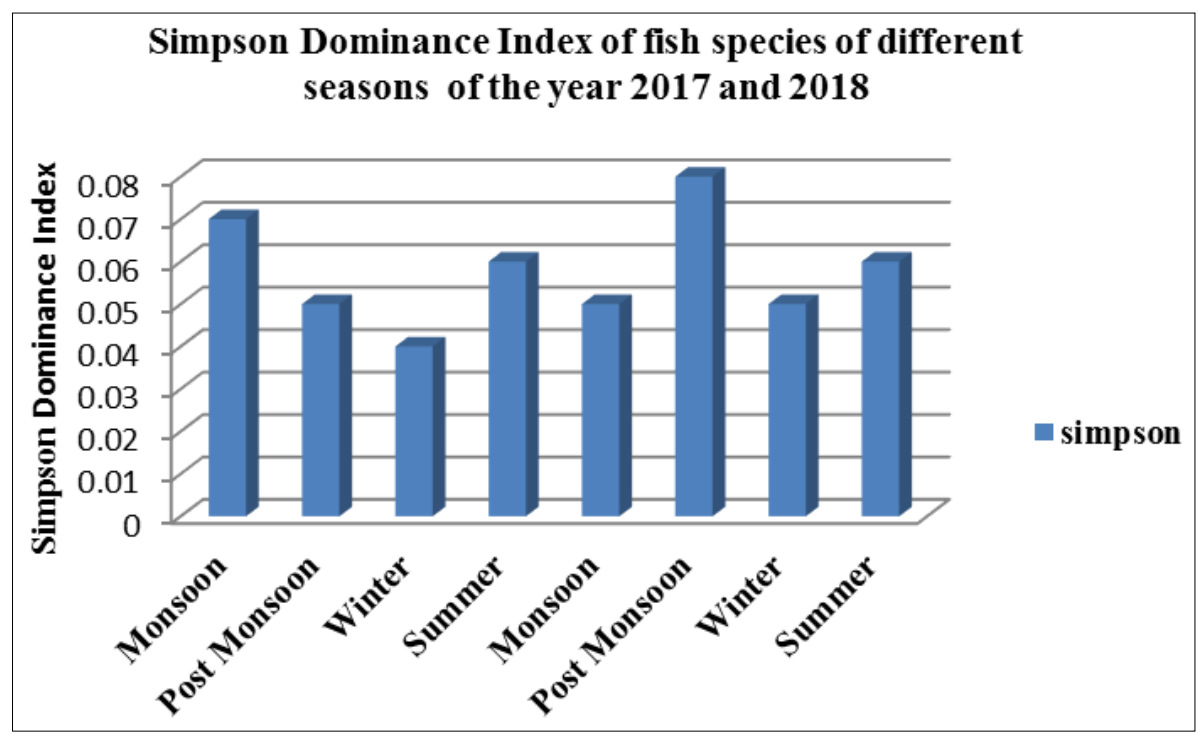

Fig 2a: showing Simpson Dominance Index of fish species of different seasons of the year 2017 and 2018

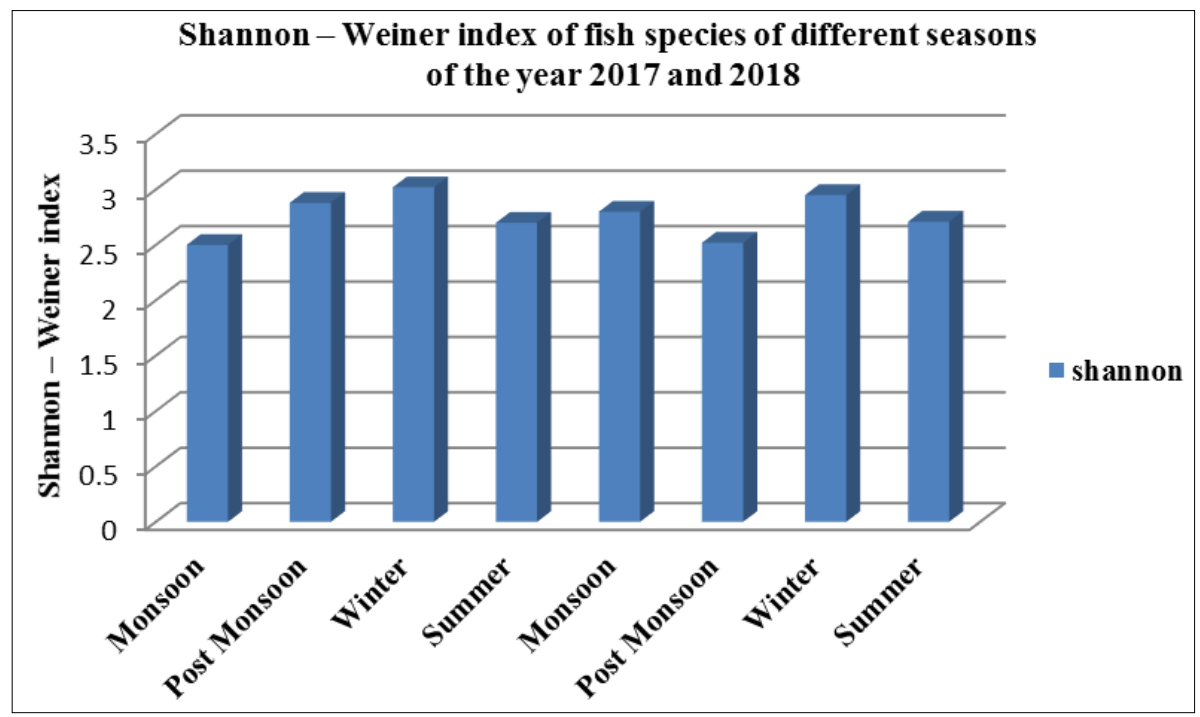

Fig 2b: Shannon - Weiner index of fish species of different seasons of the year 2017 and 2018

\section{Conclusion}

From the present study it is concluded that the Dilawara Reservoir harbours rich fish diversity particularly of family
Cyprinidae. It is therefore recommended that special enhancement programmes are required to initiate sustainable use of fisheries resources. Anthropogenic stress also impacts a 
negative impression on fish production as well as on entire reservoir ecology. Reservoir authorities should maintain water level particularly during summers and also take necessary steps to minimize the human activities in and around the reservoir and they have to regularly check the physicochemical and biological parameters to prevent any depletion of reservoir ecology.

\section{References}

1. Battul PN, Rao RA, Navale KR, Bagale MB, Shah NV. Fish Diversity from Ekrukh Lake Near Solapur Maharashtra, J Aqua. Biol 2007;22(2):68-72.

2. Daniels RJR. Project Lifescape 6. Freshwater Fishes: Catfishes. Resonance 2000;5(4):95-107.

3. Hamzah N. Assessment on water quality and biodiversity within Sungai Batu Pahat. Master of thesis. Universiti Teknologi Malaysia 2007, 124.

4. Jayaram KC. The fresh water fishes of Indian region. Narendra Publishing House Delhi 1999, 557.

5. Khedkar GD, Gynanath G. Biodiversity and Distribution of the Fishes from the Back Waters of Issapur Reservoir District Yeotmal, Maharashtra State India. Trends in Life Science (India) 2005;20:2-117.

6. Koumans FP. Gobioidea. The Fishes of the IndoAustralian Archipelago. Eds Webe \& De Beaufort. Vol. X Gobioidea 1953, 423.

7. Kumar JAKP, Dwivedi AC, Kumar ASN, Mahesh V, Benakappa S. Ichthyofaunal diversity of Faizabad district (Uttar Pradesh), India. Journal of Experimental Zoology India 2013;16:149-154.

8. Kumar J, Panday AK. Present status of ichthyofaunal diversity and impact of exotics in Uttar Pradesh, Journal of Experimental Zoology India 2013;16(2):429-434.

9. Lakra WS, Pandey AK. Fish germplasm resources of India with special emphasis on conservation and rehabilitation of threatened species. In: Aquaculture Management, 2009, 85-104.

10. Laxmappa B, Ravinder RB. Types of fishing gears operating and their impact on Krishna river fishery in Mahabubnagar district, T.S. Indianternational Journal of Fisheries and Aquatic Studies 2014;2:30-41.

11. Mondal DK, Kaviraj A. Distribution of fish assemblages in two floodplain lakes of North 24 - Parganas in West Bengal, India, Journal of Fisheries and Aquatic Science 2009;4:12-21.

12. Mondal DK, Kaviraj A, Saha S. Water Quality Parameters and Fish Biodiversity Indices as Measures of Ecological Degradation: A Case Study in Two Floodplain Lakes of India. J Water Resource and Protection 2010;2:85-92.

13. Masuda Ho, Amaoka K, Aaga C, Uyeno T, Yoshino T. The Fishes of the Japanese. ArchiPelago Tokai University Press, Tokyo 1984.

14. Mustapha MK. Limnological evaluation of the fisheries potentials and productivity of a small shallow tropical African reservoir. Int. J Trop. Biol 2009;57:1093-1106.

15. Mondal DK, Kaviraj A. Distribution of fish assemblages in two floodplain lakes of North 24 - Parganas in West Bengal, India, Journal of Fisheries and Aquatic Science 2009;4:12-21.

16. Pandey AK, Das P. Current status of fish germplasm resources of India and strategies for conservation of endangered species. In: Proceedings of Recent Advances in Applied Zoology 2006, 1-39.
17. Talwar PK, Jhingran Arun G. Inland Fishes of India and Adjacent Countries 1991;1\&2:1158.

18. Thirumala S, Kiran BR, Kantaraj GS. Fish diversity in relation to physico-chemical characteristics of Bhadra reservoir of Karnataka, India. Advances in Applied Science Research 2011;2(5):34-47.

19. Tiwari RN. A ssessment of groundwater quality and pollution potential of Jawa Block, Rewa District, Madhya Pradesh, India, Proceedings of the International Academy of Ecology and Environmental Sciences. International Academy of Ecology and Environmental Sciences 2011;1 3(4):202-212.

20. Laxmappa B, Ravinder Rao Bakshi. Types of fishing gears operating and their impact on Krishna river fishery in Mahabubnagar district, T.S. India. Int. J Fisheries and Aquatic Studies 2014;2:30-41.

21. Ubarhande SB, Jagtap JT, Sonawane SR. Ichthyofanal Diversity from Ambadi Dam, Taluka Kannad, District Aurangabad (Maharashtra), Recent Research in Science and Technology 2011;3(6):34-37. 